\section{Volume 3 • Nomor 1 • Oktober 2019 \\ Pege $($ Hal. $): 55-68$}

website. :

http://www.openjournal.unpam.ac.id/index.php/JPK
(C) Universitas Pamulang

JL.Surya Kencana No.1 Pamulang, Tangerang Selatan - Banten

Telp. (021) 7412566, Fax (021) 7412491 Email : jurnalmarketing.unpam@gmail.com

\title{
Analisa Brand Image Dalam Pengambilan Keputusan Memilih Perguruan Tinggi
}

\author{
Dewi Ningsih ${ }^{1}$ \\ Universitas Pamulang, dosen02453@unpam.ac.id
}

\begin{abstract}
Abstrak. Penelitian ini bertujuan untuk mengetahui citra merek yang terdapat di Universitas Pamulang, sehingga mampu mempengaruhi mahasiswa memilih Universitas Pamulang. Metode yang terdapat pada penelitian ini, peneliti menggunakan phenomenological method. Dalam pengumpulan data di penilitian ini peneliti menggunakan metode snowball sampling.

Brand Image atau citra merek yang selama ini berusaha disampaikan kepada masyarakat luas sudah berhasil diterima. Seperti ketika masyarakat khususnya mahasiswa mendengar kata "Unpam" maka mereka langsung mengingat bahwa Universitas Pamulang merupakan Perguruan Tinggi memiliki harga terjangkau untuk semua lapisan masyarakat, memiliki fasilitas yang sangat baik seperti gedung yang besar, dan memiliki kualitas yang baik. Brand image dalam pengambilan keputusan mahasiswa memilih kampus sangat dipertimbangkan oleh mahasiswa, mereka memilih Perguruan Tinggi ini karena mempertimbangkan biaya yang harus dikeluarkan selama berkuliah, mereka melihat gedung yang sangat besar, dan mendengar rekomendasi dari teman - teman mereka bahwa Universitas Pamulang merupakan kampus yang berkualitas dibuktikan dengan saat ini memiliki Akreditas B pada program studi Manajemen S1.
\end{abstract}

\section{Keywords: Citra Merek; Keputusan}

Abstract. This research aims to identify brand image of the University of Pamulang, that influenced students in choosing Pamulang University.

The methods contained in this study researchers used the phenomenological method. In the collection of data in this research researchers use the snowball sampling method.

Brand image that has been trying to convey to the wider community has been successfully received. Like when the public especially students hear the word "Unpam" then they immediately remember that Pamulang University is a higher education that has affordable ptices for all walks of life, has excellent facilities such us a large buildings, and has a good quality. Brand image in student decision making choosing a campus is highly considered by students, they choose this university because it considers the costs incurred during college, they see a very lage building, and hear recommendations from their friends that Pamulang University is a quality campus as evidenced by currently having a $B$ accreditation in the S1 Management study program.

Key words: brand image; decision

\section{A. PENDAHULUAN}

Universitas Pamulang memiliki fakultas yang cukup berfariasi, seperti fakultas hokum, fakultas sastra, fakultas teknok, fakultas keguruan dan ilmu pendidikan, fakultas matematika dan ilmu pengetahuan alam, fakultas ekonomi, program pasca sarjana, dan sekolah tinggi ilmu kesehatan atau STIKES. Di bawah ini merupakan tabel 1.1 yang menerangkan jumlah mahasiswa yang diterima di Universitas Pamulang dari tahun ke tahun, khususnya di jurusan 
Manajemen. Pada dasarnya setiap tahun mahasiswa yang diterima di Universitas Pamulang bertambah, karena banyaknya jurusan yang terdapat di Universitas Pamulang, maka jumlah tersebut terbagi disetiap jurusan perkuliahan.

Tabel 1.1

Mahasiswa Manajemen yang diterima di Universitas Pamulang

\begin{tabular}{|c|c|c|c|}
\hline Tahun & $\mathbf{2 0 1 6}$ & $\mathbf{2 0 1 7}$ & $\mathbf{2 0 1 8}$ \\
\hline Jumlah & 5634 & 5488 & 1401 \\
\hline
\end{tabular}

\author{
Sumber : Staff Prodi Manajemen S1 \\ Universitas Pamulang
}

Harga yang murah dan tetap memiliki kualitas saat ini telah menjadi brand image bagi Universitas Pamulang. Hal itu telah melekat di seluruh pikiran masyarakat bahwa UNPAM merupakan kampus dengan biaya yang terjangkau.

Berdasarkan temuan awal peneliti dan diskusi oleh Rektor dari Universitas Pamulang , masalah - masalah tersebut telah terjabarkan pada alinea di atas, masalah - masalah tersebut adalah seputar brand image yang mampu mempengaruhi masyarakat dan calon mahasiswa untuk berkuliah di Universitas Pamulang. Oleh karena itu, penulis memberi judul terhadap penelitian ini yaitu "Analisa terhadap Keputusan Mahasiswa Memilih Universitas Studi Kasus Universitas Pamulang".

Rumusan masalah dalam penelitian ini : 1.Bagaimana brand image mahasiswa pada Universitas Pamulang saat ini? 2.Bagaimana pengambilan keputusan mahasiswa dalam memilih Universitas Pamulang?

Tujuan penelitian ini adalah: 1.Untuk mengetahui brand image mahasiswa pada Universitas Pamulang saat ini? 2.Untuk mengetahui pengambilan keputusan mahasiswa dalam memilih Universitas Pamulang?

\title{
B. KAJIAN LITERATUR
}

Citra merek (Brand image)

Merupakan representasi dari keseluruhan persepsi terhadap merek dan dibentuk dari informasi dan pengalaman masa lalu terhadap merek itu. Menurut Setiadi (2001: 180) mengungkapkan bahwa citra merek berhubungan dengan sikap yang berupa keyakinan dan perferensi terhadap suatu merek. Konsumen yang memiliki citra yang positif terhadap suatu merek, akan lebih memungkinkan untuk melakukan pembelian.

Kotler dan Amstrong (2014 : 233) menyatakan bahwa citra merek adalah "The set of belief held about a particular brand is known as brand image". Yang artinya adalah sekumpulan keyakinan terhadap suatu merek disebut citra merek.

Keputusan Pembelian

Keputusan pembelian didefinisikan oleh Kotler \& Keller (2016 : 198), 
"In the evaluation stage, the consumer forms preferences among the brands in the choice and may also form an intention to buy the most preferred brand".

Berikut merupakan lima tahap proses pembelian konsumen menurut Kotler dan Amstrong (2014 : 176) beserta penjelasannya adalah sebagai berikut :

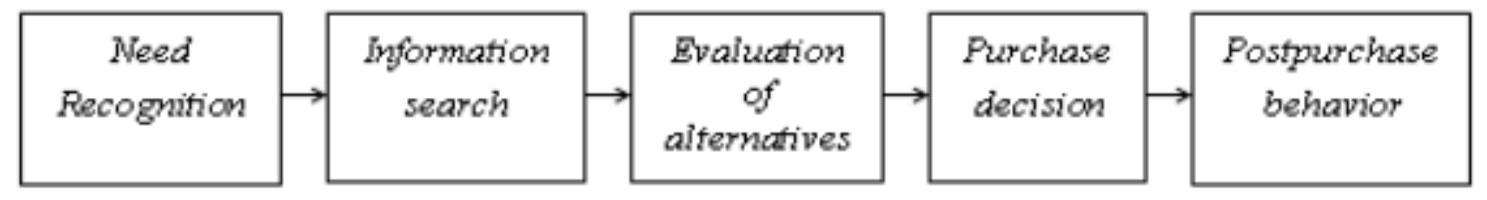

Gambar 2.1.

Proses Keputusan Pembelian

\section{METODOLOGI PENELITIAN}

Pelaksanaan penelitian ini bertempat di Universitas Pamulang di jalan Surya Kencana No.1 Pamulang Barat, Kecamatan Pamulang. Kota Tangerang Selatan. Propinsi Banten, Kode Pos 15417. Tlp. (021) 7412566 - 74709855. Fax. (021) 7412566. www.unpam.ac.id

Waktu yang diperlukan dalam penelitian ini mulai dari persiapan, pelaksanaan, dan penyusunan laporan mulai dari bulan Desember 2017 sampai dengan Mei 2018.

Dalam penelitian ini pendekatan yang digunakkan adalah pendekatan kualitatif dengan jenis penelitian fenomenologi. Creswell (2009) dalam Sugiyono (2017:14) phenomenological research is a qualitative strategy in which the researcher indentifies the essence of human experiences about a phenomenon as describe by participants in a study. (Fenomenologis merupakan salah satu jenis penelitian kualitatif dimana peneliti melakukan pengumpulan data dengan observasi partisipasi untuk mengetahui fenomena esensial partisipan dalam pengalaman hidupnya).

Jadi dari pengertian tersebut menjelaskan bahwa metode ini digunakan karena adanya masalah yang fenomenal, dan metode ini juga bertujuan untuk mengumpulkan data guna mengetahui fenomena apa yang sebenarnya terjadi. Di atas juga dijelaskan bahwa pertama kali hal yang dilakukan adalam meng-obsevasi objek yang diduga memiliki fenomena tersebut untuk diteliti lebih lanjut.

Teknik sampel penelitian yang digunakan adalah teknik bola salju (snowball) merupakan jenis teknik mengumpulkan data sample yang dilakukan melaui seseorang dengan orang yang lainnya (responden) yang saling berkaitan dan berhubungan, sehingga akan ditemui suatu kasus yang berhubungan dengan satu orang terhadap orang lainnya.

Saat melalukan teknik sampling bola salju (snowball) maka didapati beberapa kriteria menurut Neuman (2001) dalam Nina Nurdiani (2014:1113). Teknik sampling snowball adalah 
suatu metode yang dapat digunakkan untuk mengidentifikasi, memilih, dan mengambil sampel dalam suatu jaringan atau rantai yang terhubung secara terus menerus.

\section{HASIL DAN PEMBAHASAN}

\section{Sejarah Singkat Universitas Pamulang}

Darsono (2018:2-5) mengatakan Universitas Pamulang (selanjutnya kami sebut Unpam) didirikan tujuh belas tahun yang lalu, tepatnya pada tahun 2001 di Kota Tangerang Selatan Provinsi Banten oleh Yayasan Prima Jaya. Pada masa Unpam dikelola Yayasan Prima Jaya, mahasiswa dikenakan biaya gedung dan biaya kuliah seperti PTS pada umumnya. Ternyata kebijakan Yayasan Prima Jaya tersebut tidak sesuai dengan kemampuan masyarakat yang menjadi stakeholder-nya.

Sebagian besar mahasiswa yang masuk ke Unpam di bawah Yayasan Prima Jaya merupakan kelompok masyarakat marginal yang secara ekonomi kurang mampu. Akibatnya Unpam mengalami kesulitan untuk menyelenggarakan proses belajar mengajar dikarenakan rendahnya kemampuan Yayasan Prima Jaya, sehinnga Yayasan ini tidak sanggup lagi mengelola Unpam. Kegagalan ini berakibat Unpam diserahkan kepada Yayasan Sasmita Jaya (berikutnya dalam orasi ilmiah disebut Sasmita Jaya) di bawah pimpinan Drs. H. Darsono pada tahun 2004. Saat itu jumlah mahasiswa, baru ada 120 orang, yang tersebar ke dalam 10 program studi. Meskipun mahasiswa Unpam hanya sejumlah itu, namun pendidikan bagi mereka harus berjalan dengan baik sesuai dengan tuntutan kurikulum pendidikan tinggi. Untuk membantu mereka dengan sengaja Sasmita Jaya menetapkan uang kuliah hanya sebesar Rp. 100.000 per bulan. Mengapa kami melakukan hal tersebut? Hal itu dilakukan karena ada rasa keprihatinan kami terhadap mahasiswa tersebut. Mahasiswa yang datang pada semester awal itu, berasal dari kelompok masyarakat marginal. Oleh karenanya mereka perlu dibantu secara finansial agar bisa kuliah di Unpam sampai selesai.

\section{Universitas Pamulang Masa Kini}

Darsono (2018:6-9) mengatakan bahwa Unpam ketika masih berada dibawah penyelenggaraan Yayasan Prima Jaya, menghadapi banyak keterbatasan dilihat dari animo mahasiswa untuk masuk Unpam yang berdampak pada tidak sehatnya keuangan untuk menyelenggarakan proses pembelajaran. Kondisi ini membuat kami di Sasmita Jaya tertantang untuk mengambil langkah - langkah strategis agar Unpam bisa keluar dari permasalahan yang dihadapi saat itu dengan cara mengumpulkan semua orang tua mahasiswa untuk menyampaikan kebijakan Unpam berupa : (a) penghapusan uang gedung; (b) penghapusan uang SKS; (c) penetapan uang kuliah relative rendah dan dapat dicicil disesuaikan dengan kemampuan orang tua mahasiswa. Di samping itu, manajemen pembelajaran di Unpam sesuai dengan ketersediaan waktu mereka. Sejak itulah Unpam mengalami kemajuan uang signifikan dilihat dari aspek kemahasiswaan, dosen, tenaga kependidikan dan sarana prasarana.

\section{Lambang Universitas Pamulang}

Lingkaran luar yaitu bola mengandung arti bahwa Yayasan Sasmita Jaya dan Universitas Pamulang mengacu ke pengembangan dunia dan era Globalisasi yang tak putus-putus Jurnal Pemasaran Kompetitif, Vol. 03, No. 1 / Oktober 2019 
namun merupakan satu kesatuan yang bulat Empat segitiga besar dan empat segitiga kecil mengandung arti bahwa Universitas Pamulang memiliki pijakan dari empat sisi landasan kehidupan baik langkah-langkah besar maupun lankah-langkah kecil selalu berlandaskan pada empat hal yaitu :

Iman yaitu seluruh aktifitas selalu berlandaskan kepercayaan kepada Tuhan Yang Maha Esa IImu yaitu seluruh aktifitas akademik berpijak kepada sisi keilmuan Amal yaitu pelaksanaan Tri Dharma Perguruan Tinggi merupakan wujud amal bakti Akhlak yaitu seluruh amal sebagai wujud Tri Dharma Perguruan Tinggi dihiasi oleh akhlak yang baik.

Lingkaran Utama plat merah mengandung arti bahwa Universitas Pamulang mengemban misi yang utama tidak terpisah-pisah dan bersifat bulat antara pikir dan dzikir, antara iman dan ilmu, ilmu dan amal, amal dan akhlak jasmani dan rohani sebagai suatu lingkaran kehidupan Bunga yang mekar di dalam lingkaran utama memiliki arti Universitas Pamulang membina, mendidik, mengarahkan dan membimbing para mahasiswa sebagai harapan bangsa yang sedang mekar, yang akan mengharumkan bangsa dan menghasilkan buahbuah yang bermanfaat bagi nusa dan bangsa.

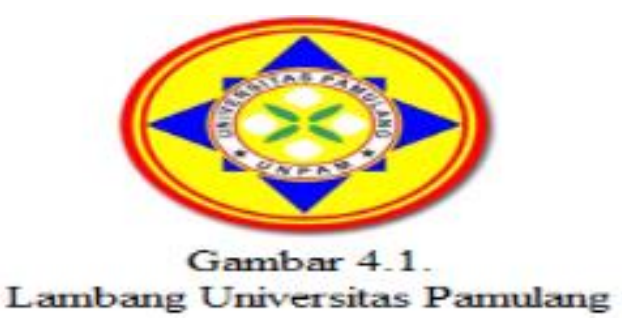

Visi dan Misi Universitas Pamulang

a. Visi dari Universitas Pamulang

Bermutu dalam pengembangan pendidikan, penelitian, dan pengabdian terjangkau seluruh lapisan masyarakat, berlandaskan ridha tuhan yang maha esa.

b. Misi dari Universitas Pamulang

1.Menyelenggarakan pembelajaran keilmuan dan keterampilan, riset beriring pengabdian pada masyarakat yang berkualitas dengan mempertimbangkandaya jangkau semua kalangan.

2.Melakukan kerjasama lintas lembaga menunjang sinerjitas dan motivasi kompetitif kajian dan implementasi Tri Darma Perguruan Tinggi.

3.Mengintensifkan studi nilai-nilai dan norma-norma religiusitas terkait ketuhanan, peribadatan, akhlak mulia, keilmuan, dan kehidupan yang hasilnya diintegrasikan mengaura ke dalam mata kuliah secara relevan.

4.Meningkatkan kualitas pelayanan menggapai tata kelola universitas modern pada tahun 2020.

5.Menciptakan lulusan (Ahli Madya, Sarjana, dan Magister) profesional dalam kompetensinya, berjiwa mandiri dan berakhlak mulia yang dilandasi nilai dan norma keimanan dan ketakwaan kepada Tuhan Yang Maha Esa.

\section{Brand Image Universitas Pamulang}


Brand image atau citra merek merupakan hal terpenting yang harus terdapat dalam sebuah produk baik itu produk berupa barang maupun jasa. Karena citra merek dapat menjadi gambaran atau refleksi dari suatu produk tersebut yang akan dipikirkan oleh seseorang. Saat ini brand image atau citra merek yang dimiliki oleh Universitas Pamulang dapat dikelompokan berdasarkan : (a) Recognition (pengakuan); (b) Reputation (reputasi); (c) Affinity (afinitas); (d) Domain. Citra merek tersebut akan terbangun dengan baik jika sebuah kampus atau perguruan tinggi memiliki kualitas yang baik di pikiran masyarakat. Semua hal tersebut dapat terbentuk jika suatu perguruan tinggi sudah memiliki kualitas yang baik. Saat saya berbincang - bincang dengan salah satu mahasiswa di Universitas Pamulang Program Studi Manajemen bernama Adji Sri Wahyudi menyatakan bahwa "perguruan tinggi yang baik adalah perguruan tinggi yang dikenal masyarakat, yang mempunyai reputasi baik di masyarakat".

Jadi untuk menciptakan brand image atau citra merek yang positif di masyarakat maka perguruan tinggi tersebut haruslah dimulai menjadi perguruan tinggi yang berkualitas, dikenal oleh masyarakat, dan memiliki reputasi baik di masyarakat. Untuk mencapai kesuksesan seperti saat ini, Universitas Pamulang atau Unpam selalu memualinya dari hal yang terkecil, seperti mempromosikan perguruan tingginya dengan menanamkan branding kepada masyarakat luas, sehingga saat ini Universitas Pamulang dapat dikenal dengan baik oleh seluruh masyarakat khususnya masyarakat Tangerang Selatan, serta memiliki reputasi baik di mata masyarakat luas.

Brand image atau citra merek yang dimiliki oleh Universitas Pamulang (Unpam) dapat diuraikan berdasarkan dimensinya yaitu sebagai berikut :

a.Recognition (Pengakuan)

Recognition atau pengakuan merupakan tingkat dikenalnya sebuah merek oleh konsumen. Jadi di sini jelas merupakan tingkat dikenalnya Universitas Pamulang atau Unpam oleh masyarakat luas khususnya mahasiswa yang telah memilih Universitas Pamulang untuk tempat berkuliahnya. Mahasiswa tersebut memilih Universitas Pamulang atau Unpam sebagai tempat berkuliah tentunya memiliki pertimbangan sebelum benar - benar memilihnya, salah satu pertimbangan bagi mereka merupakan pengakuan tentang Universitas Pamulang atau Unpam di masyarakat luas.

Pengakuan tersebut berupa penilaian tentang Universitas Pamulang atau Unpam yang baik seperti memiliki kualitas yang baik, memiliki dosen pengampu yang berkualitas, dan memiliki sarana dan prasarana pembelajaran yang lengkap dan memadai. Selain itu mahasiswa yang memilih dan memutuskan untuk berkuliah di Universitas Pamulang atau Unpam ini juga memiliki pertimbangan dari segi biaya yang akan dikeluarkan dari pendaftaran hingga akhir mereka berkuliah, mereka semua hampir berpendapat bahwa mereka memilih Universitas Pamulang atau Unpam karena biaya yang akan dikeluarkan oleh mereka selama berkuliah tergolong relatif terjangkau bila dibandingkan oleh Perguruan Tinggi lainnya. Karena saat ini pengakuan tentang Universitas Pamulang atau Unpam di mata masyarakat khususnya mahasiswa dan mahasiswi adalah, Universitas Pamulang merupakan Perguruan Tinggi yang diakui sebagai Perguruan Tinggi yang paling memiliki harga terjangkau untuk kalangan menegah keatas dan menengah kebawah, walaupun memiliki harga yang relatif terjangkau jika dibandingkan dengan Perguruan Tinggi lainnya, namun Universitas Pamulang atau Unpam memiliki kualitas yang baik hal ini dibuktikan dengan akreditasi di Prodi Manajemen yaitu $B$, memiliki dosen pengampu yang berkualitas, memiliki fasilitas yang baik, dan sarana prasarana pembelajaran yang lengkap.

b.Reputation (Reputasi)Reputation atau reputasi merupakan tingkat atau status yang cukup tinggi bagi sebuah merek karena terbukti memiliki track record yang baik. Jadi di sini merupakan status yang bersangkutan dengan Universitas Pamulang atau Unpam di masyarakat luas khususnya mahasiswa dan mahasiswi yang berupa akreditas ataupun tampilan dari Perguruan Tinggi tersebut, tampilan yang dimaksud disini adalah seperti 
gedung yang menjadi tempat proses pembelajaran di Universitas Pamulang atau Unpam. Dalam hal reputasi yang dimiliki oleh Universitas ini, tentunya dapat menjadi bahan pertimbangan yang penting bagi mahasiswa yang berkuliah di Universitas Pamulang atau Unpam, mereka memiliki pertimbangan sebelum masuk ke Universitas ini. Pertimbangan tersebut yaitu tentang akreditas B yang dimiliki oleh Program Studi Manajemen di Universitas Pamulang atau Unpam. Karena mereka berpendapat bahwa Perguruan Tinggi yang memiliki akreditas yang baik (dalam hal ini Universitas Pamulang memiliki akreditasi B) merupakan reputasi atau status bagi sebuah Perguruan Tinggi, selain itu memiliki gedung yang sangat besar dan bagus serta berfasilitas lengkap juga sebagai status bagi Universitas Pamulang atau Unpam.

c.Affinity (Afinitas)

Affinity atau afinitas merupakan suatu emosional relationship yang timbul antara sebuah merek dengan konsumennya. Seperti halnya jika sebuah produk yang dikenal dan lebih disukai oleh masyarakat pasti produk tersebut akan mudah terjual dan lebih diminati oleh masyarakat. Tentunya hal ini juga menjadi pertimbangan mahasiswa dan mahasiswi dalam memutuskan untuk berkuliah di Universitas Pamulang. Mereka berpikir bahwa Universitas Pamulang atau Unpam lebih disukai oleh masyarakat jika dibandingkan dengan perguruan tinggi lain, hal ini menjadi pertimbangan tersendiri bagi mereka dalam memutuskan tempat berkuliah. Seperti di Universitas Pamulang memiliki dosen pengampu yang berkualitas dan menguasi mata kuliah yang diajarkan, selain dosen yang berkualitas hal lain yang menjadi pertimbangan mereka adalah banyaknya jumlah mahasiswa dan mahasiswi yang berkuliah di Universitas Pamulang. Mahasiswa dan mahasiswi ini sangat banyak dan meningkat jumlahnya setiap tahun, mereka berpendapat hal ini membuktikan bahwa Universitas Pamulang atau Unpam lebih disukai apabila dibandingkan dengan Pergutuan Tinggi lainnya yang terdapat disekitarnya.

d.Domain

Domain ini menyangkut seberapa besar scope atau jangkauan dari sebuah produk yang akan menggunakan produk tersebut. Jadi ini dapat dikatakan merupakan jangkauan dari mana saja yang akan berkuliah di Universitas Pamulang atau Unpam. Hal ini tentunya menjadi pertimbangan setiap mahasiswa memperhitungkan jarak dan jangkauan antara rumahnya dan Perguruan Tinggi tersebut. Mahasiswa dan mahasiswi mempertimbangkan beberapa hal saat mereka benar - benar memutuskan untuk berkuliah di Universitas Pamulang atau Unpam, hal tersebut yaitu letak dari Perguruan Tinggi ini. Universitas Pamulang atau Unpam menurut mahasiswa dan mahasiswi ini memiliki lokasi yang strategis dan sangat mudah untuk dicari dan dijangkau. Selain lokasi yang sangat strategis, mereka berpendapat bahwa mudahnya transportasi umum yang menuju ke Universitas ini, selain menggunakan ojek online, angkutan umum konvensional pun banyak yang menjangkau Universitas Pamulang. Sehingga ini menjadi poin tambahan saat mereka mempertimbangkan untuk memutuskan berkuliah di Universitas Pamulang (UNPAM).

Selain berdasarkan observasi dan interview yang telah dilakukan oleh peneliti secara mendalam (indeep interview) kepada responden yaitu adalah mahasiswa ataupun mahasiswi Strata 1 (satu) Program Studi Manajemen di Universitas Pamulang serta berdasarkan dengan hasil pengalaman pribadi yang telah dialami oleh peneliti karena dalam hal ini posisi peneliti selain sebagai peneliti juga sebagai informan kunci atau key informan karena peneliti adalah bagian dari mahasiswa Universitas Pamulang atau Unpam dapat dideskripsikan melalui jawaban responden terhadap pertanyaan - pertanyaan yang digunakan untuk mengukur variabel brand image Universitas Pamulang. Dengan menggunakan pertanyaan pertanyaan yang diajukan melalui kuesioner yang memiliki 4 indikator yaitu recognition (pengakuan), reputation (reputasi), Affinity (afinitas), dan domain yang kemudian dijabarkan menjadi 20 pertanyaan. Berikut ini adalah hasil tanggapan responden terhadap masing masing dimensi yang mewakili setiap indikator. 
Tabel 4.2.

Rekapitulasi Rata-Rata Penilaian Responden Mengenai Brand Image Universitas Pamulang dalam Pengambilan Keputusan

\begin{tabular}{|r|l|c|r|c|}
\hline No & \multicolumn{1}{|c|}{ Dimensi } & $\begin{array}{c}\text { Skor Rata - } \\
\text { Rata }\end{array}$ & Presentase & $\begin{array}{c}\text { Kriteria } \\
\text { Penilaian }\end{array}$ \\
\hline 1 & Recognition (Pengakuan) & 4 & $20.10 \%$ & Baik \\
\hline 2 & Reputation (Reputasi) & 6.95 & $35.00 \%$ & Baik \\
\hline 3 & Affinity (Afinitas) & 5.95 & $30.00 \%$ & Baik \\
\hline 4 & Domain & 3 & $20.00 \%$ & Baik \\
\hline \multicolumn{2}{|c|}{ Rata - Rata } & $\mathbf{4 . 9 7 5}$ & $\mathbf{2 6 . 2 8} \%$ & Baik \\
\hline
\end{tabular}

Sumber : Hasil olah data peneliti

Berdasarkan data di atas yang dianalisa dari hasil wawancara terhadap responden yang telah dilakukan, maka diketahui hasil dari variabel brand image atau citra merek yang dimiliki oleh Universitas Pamulang atau Unpam yaitu dari indikator recognition atau pengakuan didapatkan skor rata - rata sebesar 4 atau jika dipresentasikan menjadi 20.10\%. Yang kedua adalah indikator reputation atau reputasi yang dimiliki oleh Univsersitas Pamulang atau Unpam didapatkan skor rata - rata sebesar 6.95 atau jika dipresentasikan menjadi $35 \%$. Selanjutnya adalah indikator affinity atau afinitas yang terjalin antara Universitas Pamulang atau UNPAM dengan mahasiswa/i didapati skor rata - rata sebesar 5.95 atau yang apabila dipresentasekan menjadi 30\%. Dan yang terskhir adalah indikator domain dari Universitas Pamaulang yang setelah dihitung didapatkan skor rata - rata sebesar 3 yang apabila dipresentasekan menjadi $20 \%$. Seluruh hasil tersebut diperoleh dari olah data sesuai dengan data interview yang telah dilakukan sebelumnya kepada mahasiswa dan mahasiswi Universitas Pamulang S1 Prodi Manajemen.

2. Brand image Universitas Pamulang dalam pengambilan keputusan mahasiswa Universitas Pamulang atau UNPAM ini sesungguhnya memiliki visi yang baik dan mulia, visi tersebut adalah bermutu dalam pengembangan pendidikan, penelitian, dan pengabdian terjangkau seluruh lapisan masyarakat, berlandaskan ridha Tuhan Yang Maha Esa. Jadi Universitas Pamulang ini didirikan karena memiliki tujuan untuk mengadakan pendidikan yang sangat terjangkau untuk seluruh lapisan masyarakat tanpa meninggalkan kualitas dan mutunya.

Untuk mampu menjadi sebuah Perguruan Tinggi Swasta (PTS) yang dipercaya oleh masyarakat luas maka Universitas Pamulang (UNPAM) harus melakukan promosi secara baik dan berkelanjutan, baik itu secara langsung ataupun melalui media. Selain melakukan promosi, Universitas Pamulang juga harus memiliki diferensiasi yang nantinya akan menjadi citra merek di kalangan masyarakat luas. Hal ini bertujuan untuk menanamkan branding dari Universitas Pamulang atau Unpam itu sendiri kepada masyarakat luas. Jadi jika brand image dari Universitas Pamulang atau Unpam sudah tertanam di pikiran masyarkat tentunya hal ini akan menjadi pertimbangan mahasiswa saat memilih Perguruan Tinggi untuk berkuliah.

Analisa SWOT merupakan analisa tentang konndisi internal organisai yamg berupa faktor kekuaatan atau strength dan kelemahan atau weakness maupun faktor external organisasi yang berupa peluang atau opportunity dan ancaman threat. Dengan menggunakan keempat komponen itu universitas pamulang (Unpam) dapat membuat berbagai strategi sebagai berikut :

Mengguanakan kekuatan untuk menangkap peluang yang ada.

Menggunakan kelemahan yang dimiliki untuk menangkap peluang.

Menggunakan kelemahan untuk menghandapi ancaman. 
Meminimalisir kelemahan dalam menghadapi ancaman yang datang dari luar.

Dengan menggunakan analisis SWOT dimungkinkan sebuah organisasi dapat menyusun strategi dan program kerja untuk menjadi lebih baik lagi. Seperti mengetahui kelemahan yang akan diperbaiki dan mengatahui tantangan yang akan atau sedang dihadapi sehingga hal itu mampu menjadi nilai lebih yang akan dijadikan konsumen sebagai bahan pertimbangan dalam memilih suatu organisasi.

Di bawah ini adalah hasil yang didapat peneliti saat melakukan penelitian, dan peneliti sajikan dalam bentuk deskripsi analisis SWOT Universita Pamulang atau Unpam tentang brand image atau citra merek yang dimiliki, serta srtategi yang dihasilkan dari mengkombinasi berupa strategi SO, strategi WO, strategi ST, dan strategi WT. Serta disajikan pula dalam sebuah matrix, dan pembobotan aspek internal dan eksternal.

a. Brand Image (Citra Merek) - Strenght and Weakness (Internal Gap)

1) Citra Merek - Keunggulan (Brand Image - Strenght)

Memiliki biaya pendaftaran terjangkau.

Tidak adanya biaya uang gedung.

Memiliki biaya persemester terjangkau.

Biaya persemester dapat dicicil perbulannya.

Memiliki kualitas yang baik.

Memiliki gedung perkuliahan yang bagus dan berfasilitas lengkap.

Memiliki dosen yang berkualitas.

2) Citra Merek - Kelemahan (Brand Image - Weakness)

Memiliki parkiran yang luas namun tidak mampu menampung seluruh mahasiswa.

Jumlah mahasiswa yang banyak sering membuat kemacetan saat di jam pulang kuliah.

b. Brand Image (Citra Merek) - Opportunity and Threats (Eksternal Gap)

1) Citra Merek - Peluang (Brand Image - Opportunity)

Memiliki akreditas B.

Menaikan kualitas perguruan tinggi agar lebih baik lagi.

Beberapa dosen yang belum berkompeten.

2) Citra Merek - Ancaman (Brand Image - Threats)

Mulai banyak Perguruan Tinggi lain disekitar yang mengikuti sistem cicil biaya persemester seperti di Universitas Pamulang.

Hasil dari uraian di atas dapat juga dicermati pada tabel 4.3.yaitu tabel Matriks SWOT Universitas Pamulang atau UNPAM tentang brand image menurut para mahasiswa dan mahasiswi yang berkuliah di sana adalah sebagai berikut :

\begin{tabular}{|c|c|c|}
\hline \multicolumn{3}{|c|}{$\begin{array}{l}\text { Tabel 4.3 } \\
\text { Matrix SWOT Universitas Pamulang } \\
\text { Brand Tmage }\end{array}$} \\
\hline \multirow{7}{*}{$\begin{array}{c}\text { Matrix SWOT (Brand } \\
\text { Image) }\end{array}$} & Kekuatan (Strenghe) & Kelemahan (Weakness) \\
\hline & Memiliki biaya pendaftaran terjangkau. & \multirow{3}{*}{$\begin{array}{l}\text { Memiliki parkiran yang luas namun } \\
\text { tidak mampu menampung selumuh } \\
\text { mahasiswa. }\end{array}$} \\
\hline & Tidak adanya biaya uang gedung- & \\
\hline & Memiliki biaya persemester terjangkau. & \\
\hline & \begin{tabular}{|l|} 
Biaya persemester dapat dicicil perbulannya \\
Mermiliki kualitas yang baik
\end{tabular} & \multirow{3}{*}{$\begin{array}{l}\text { Jumlah mahasiswa yang banyak } \\
\text { sering membuat kemacetan di jam } \\
\text { pulang kuliah. }\end{array}$} \\
\hline & $\begin{array}{l}\text { Memiliki gedung perkuliahan yang bagus } \\
\text { dan berfasilitas lengkap. }\end{array}$ & \\
\hline & Memiliki dosen yang berkualitas. & \\
\hline Peluang (Opportumicy) & Strategi S-O & Strategi WV-O \\
\hline Merniliki Akreditas B. & Peningkatan akreditasi menjadi A. & $\begin{array}{l}\text { Mengatur arca parkir atau } \\
\text { membuat area parkir yang baru } \\
\text { sehingga mahasiswa dapat } \\
\text { memarkir kendaraannya dengan }\end{array}$ \\
\hline $\begin{array}{l}\text { Bebcrapa dosen kurang } \\
\text { berkompeten. }\end{array}$ & $\begin{array}{l}\text { Mengadakan pelatihan bagi dosen yang } \\
\text { kourang berkompeten. }\end{array}$ & $\begin{array}{l}\text { Saat jam keluar atau jam pulang } \\
\text { kuliah harusnya tidak melalui satu } \\
\text { titik pintu, sehingga dapat mengurai } \\
\text { panjangnya antrian dan kemacetan. }\end{array}$ \\
\hline Tantangan (Threath) & Strategi S - I & Strategi W-T \\
\hline $\begin{array}{l}\text { Mulai banyak perguruan } \\
\text { tinggi lain disekitar yang } \\
\text { mengikuti sistem cicil } \\
\text { biaya persernester } \\
\text { seperti di Universitas } \\
\text { Pamulang. }\end{array}$ & $\begin{array}{l}\text { Tetap mempertahankan tidak adanya uang } \\
\text { gedumg karena saat ini. hal tersebut tidak } \\
\text { mampu diikuti oleh pergurvan tinggi lain. }\end{array}$ & $\begin{array}{l}\text { Untuk saat ini tidak ada uang } \\
\text { gedung tidak dapat diikuti perguruan } \\
\text { tinggi lain, namum kedeparnyy hal } \\
\text { ini mungkin saja akan diikuti. }\end{array}$ \\
\hline
\end{tabular}


Berdasarkan hasil perhitungan pembobotan aspek - aspek internal SWOT tentang brand image di Universitas Pamulang menunjukan skor dibobot +2.48 . Secara lebih lengkap dapat dilihat pada tabel 4.4 .

\begin{tabular}{|c|c|c|c|c|c|}
\hline Aspelk Internal & Nilai & Score & $\begin{array}{l}\text { Kineria } \\
\text { Existing } \\
\text { (SWV) }\end{array}$ & Bobot & $\begin{array}{l}\text { Skor di } \\
\text { Bobot }\end{array}$ \\
\hline $\begin{array}{l}\text { Memiliki biaya pendaftaran } \\
\text { terjangkau. }\end{array}$ & $\begin{array}{l}\text { Sangat } \\
\text { Kuat }\end{array}$ & 5 & + & $11 \%$ & +0.55 \\
\hline Tidak adanya biaya gedung. & $\begin{array}{l}\text { Sangat } \\
\text { Kuat }\end{array}$ & 5 & + & $14 \%$ & +0.7 \\
\hline $\begin{array}{l}\text { Memiliki biaya persemester } \\
\text { terjangkau. }\end{array}$ & $\begin{array}{l}\text { Sangat } \\
\text { Kuat }\end{array}$ & 5 & + & $10 \%$ & +0.5 \\
\hline $\begin{array}{l}\text { Biaya persemester dapat dicicil } \\
\text { perbulannya. }\end{array}$ & $\begin{array}{l}\text { Sangat } \\
\text { Kuat }\end{array}$ & 5 & + & $12 \%$ & +0.6 \\
\hline Memiliki kualitas yang baik. & Kuat & 4 & + & $10 \%$ & +0.4 \\
\hline $\begin{array}{l}\text { Memiliki gedung perkuliahan yang } \\
\text { bagus dan berfasilitas lengkap. }\end{array}$ & Kuat & 4 & + & $13 \%$ & +0.52 \\
\hline Memiliki dosen yang berkualitas. & Menarik & 3 & $\mp$ & $8 \%$ & +0.24 \\
\hline $\begin{array}{l}\text { Memiliki parkiran yang luas namun } \\
\text { tidak mampu menampung seluruh } \\
\text { mahasiswa. }\end{array}$ & Menarik & 3 & - & $9 \%$ & -0.27 \\
\hline $\begin{array}{l}\text { Jumlah mahasiswa yang banyak sering } \\
\text { membuat kemacetan di jam pulang } \\
\text { kuliah. }\end{array}$ & Kuat & 4 & - & $13 \%$ & -0.52 \\
\hline
\end{tabular}

Berdasarkan hasil perhitungan pembobotan aspek - aspek eksternal SWOT tentang brand image di Universitas Pamulang menunjukan skor dibobot +3.07 . Secara lebih lengkap dapat dilihat pada table 4.5 .

Tabel 4.5.

Pembobotan Aspek - Aspek Eksternal Brand Image Universitas Pamulang

\begin{tabular}{|c|c|c|c|c|c|}
\hline Aspek Eksternal & Nilai & Score & $\begin{array}{c}\text { Kinerja } \\
\text { Exixting } \\
\text { (OT) }\end{array}$ & Bobot & $\begin{array}{l}\text { Skor di } \\
\text { Bobot }\end{array}$ \\
\hline Memiliki Akreditas B & $\begin{array}{l}\text { Sangat } \\
\text { Kuat }\end{array}$ & 5 & + & $47 \%$ & +2.35 \\
\hline Beberapa dosen kurang berkompeten & Kuat & 4 & + & $33 \%$ & +1.32 \\
\hline $\begin{array}{l}\text { Mulai banyak perguruan tinggi mengikuti } \\
\text { sistem bayaran dicicil persemester }\end{array}$ & Menarik & 3 & - & $20 \%$ & -0.6 \\
\hline & & & & Total & +3.07 \\
\hline
\end{tabular}

Berdasarkan pembobotan aspek - aspek internal dan eksternal SWOT tentang brand image Universitas Pamulang atau UNPAM maka dapat disusun diagram analisis SWOT untuk mengetahui brand image Universitas Pamulang di mata mahasiswa berada pada kuadran I, II, III atau IV.

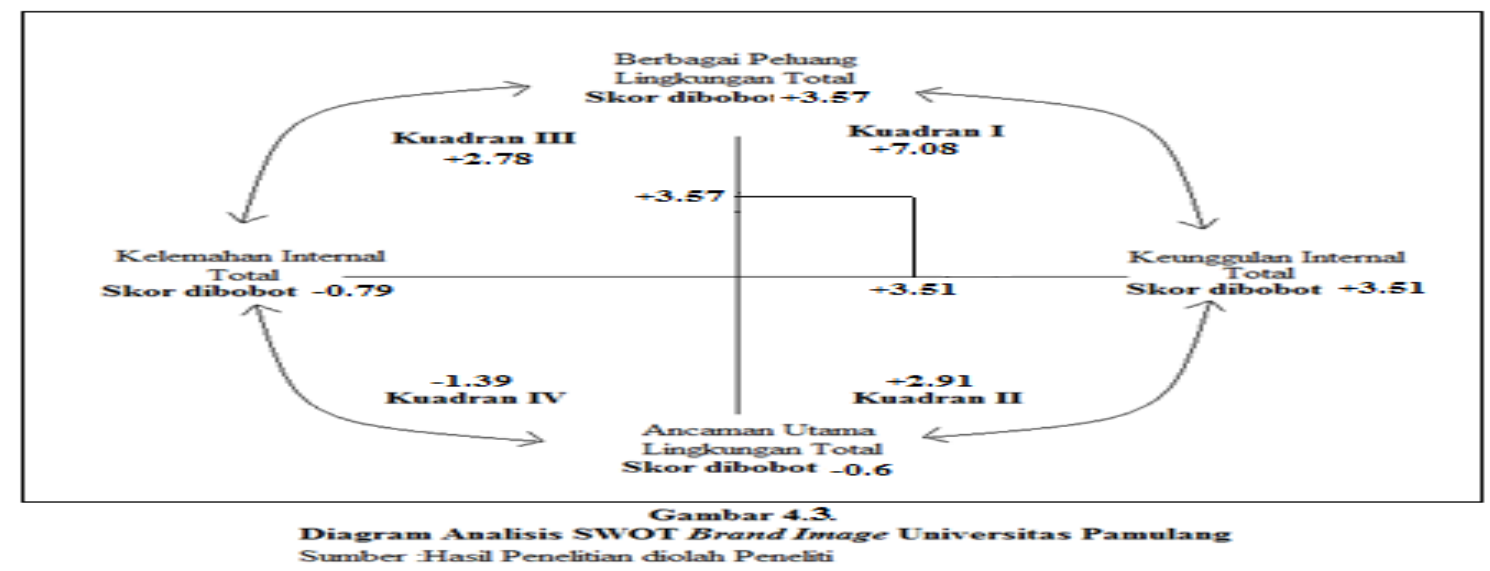


Berdasarkan diagram analisis SWOT pada gambar 4.3 tersebut, maka dapat dijelaskan bahwa kuadra I diperoleh skor sebesar +7.08, pada kuadran II diperoleh skor sebesar -2.91, pada kuadran III diperoreh skor sebesar +1.39 , dan pada kuadran IV diperoleh skor sebesar -2.78. Dengan demikian dapat dikatakan SWOT Universitas Pamulang atau UNPAM terdapat pada kuadran I. Berada di kuadran I karena Universitas Pamulang memiliki keunggulan internal yang banyak dan didukung oleh peluang sekitar lokasi.

Namun strategi - strategi yang dapat diterapkan di Universitas Pamulang atau UNPAM tidak sebatas hanya berdasarkan kuadran I tersebut, tetapi dapat dari kuadran II, kuadran III, dan kuadran IV. Di kuadran tersebut dapat diterapkan strategi dalam rangka untuk mewujudkan tujuan dari organisasi itu sendiri. Strategi - strategi yang dapat diterapkan pada masing masing kuadran adalah sebagai berikut :

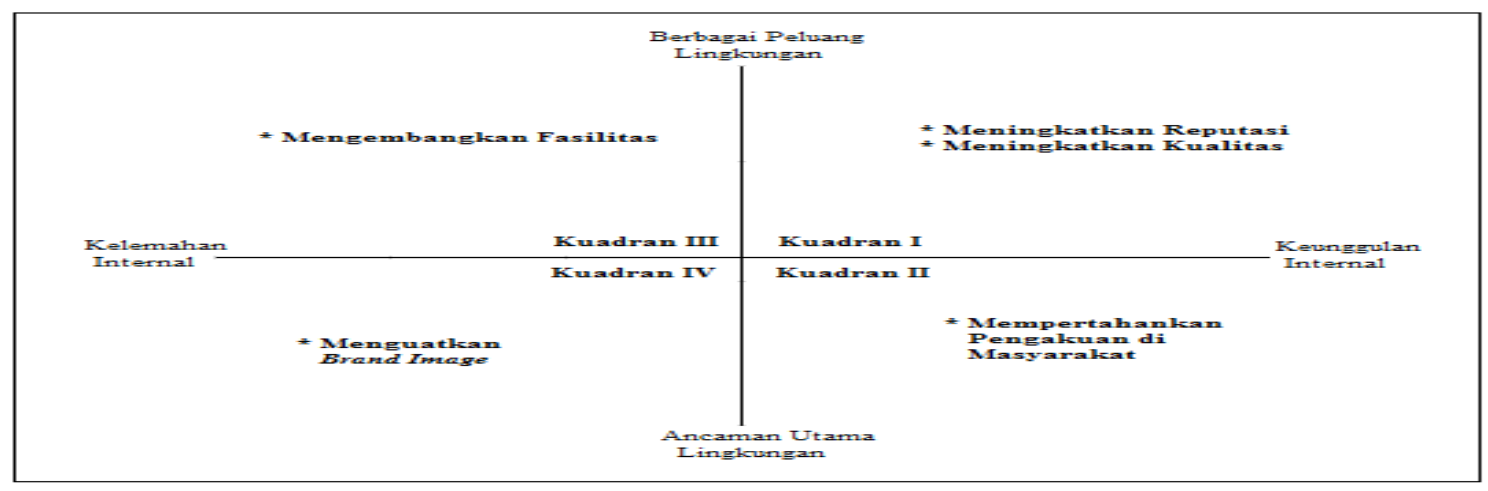

Gambar 4. 4 .

Pada kuadran I strategi yang dapat dilakukan adalah strategi meningkatkan reputasi yang terdapat pada Universitas Pamulang, reputasi yang dimiliki Universitas Pamulang khususnya prodi Manajemen adalah berakreditasi $B$. Tentunya hal ini dapat ditingkatkan untuk menjadi lebih baik lagi, bisa menjadi akreditasi A. Hal yang dapat dilakukan adalah dengan cara mengembangkan kualitas perguruan tinggi tersebut, memperketat seleksi ujian mahasiswa baru, dan meningkatkan standard penilaian terhadap mahasiswa. Kualitas juga dapat ditingkatkan melalui tenaga pengajar, dosen itu sendiri. Seperti mengharuskan dosen agar lebih memahami mata kuliah yang dibawakan. Dengan seperti itu, maka reputasi dan kualitas yang dimiliki oleh Universitas Pamulang akan menjadi lebih baik lagi, walaupun sebenarnya saat ini dapat dikatanak baik.

Pada kuadran ke II, disini strategi yang dapat dilakukan adalah dengan mempertahankan pengakuan tentang Universitas Pamulang yang berada di pikiran masyarakat. Saat ini Universitas Pamulang diakui oleh seluruh masyarakat khususnya mahasiswa sebagai satu - satunya perguruan tinggi swasta yang amat relatif terjangkau untuk seluruh lapisan masyarakat. Hal ini dibuktikan dengan biaya pendaftaran yang relatif terjangkau, karena di Universitas Pamulang ini sama sekali tidak ada uang pangkal ataupun uang gedung, namun gedung yang dimiliki oleh Universitas Pamulang ini sangatlah bagus dan megah. Selanjutnya untuk biaya persemester di Universitas Pamulang cukup terjangkau, di sini Universitas Pamulang membuat dua option bagi para mahasiswanya untuk memilih metode pembayaran, yaitu dapat membayar uang semester secara cash di awal semester atau mengasngsur di setiap bulannya. Hal ini tidak ada di perguruan tinggi lainnya, tentunya hal ini harusnya dipertahankan oleh Universitas Pamulang, karena telah menjadi brand imagenya yang sangat melekat di masyarakat luas.

Pada kuadran ke III, yang dapat dilakukan disini adalah strategi untuk menguatkan brand image. Pada awalnya mahasiswa ragu untuk masuk di Universitas Pamulang ini, brand Jurnal Pemasaran Kompetitif, Vol. 03, No. 1 / Oktober 2019 
image yang terdapat di masyarakat adalah "Universitas Pamulang adalah kampus dengan harga yang terjangkau" namun pada saat datang ke lokasi, gedung yang dimiliki perguruan tinggi ini tidak menggambarkan bahwa kampus tersebut berbiaya terjangkau relatif murah. Jadi brand image yang terdapat di Universitas Pamulang harus lebih dikuatkan kembali melakukan promosi - promosi yang dapat lebih meyakinkan calon mahasiswa untuk tetap memilih Universitas Pamulang.

Pada kuadran ke IV, strategi yang dapat dilakukan disini adalah melakukan pengembangan fasilitas, seperti halnya pengembangan fasilitas belajar mengajar yaitu pengadaan pelatihan bagi dosen yang belum menguasai materi. Pengembangan fasilitas lahan parkir yang menurut mahasiswa terkadang mereka sulit mencari parkiran untuk memarkirkan kendaraannya

\section{E. KESIMPULAN}

Berdasarkan hasil penelitian tentang Analisa Brand Image dalam Pengambilan Keputusan Memilih Perguruan Tinggi Studi Kasus Mahasiswa Manajemen Strata 1 Universitas Pamulang, maka didapati beberapa kesimpulan sebagai berikut : 1.Brand Image atau citra merek yang selama ini berusaha disampaikan kepada masyarakat luas sudah berhasil diterima. Seperti ketika masyarakat khususnya mahasiswa mendengar kata "Unpam" maka mereka langsung mengingat bahwa Universitas Pamulang merupakan Perguruan Tinggi memiliki harga terjangkau untuk semua lapisan masyarakat, memiliki fasilitas yang sangat baik seperti gedung yang besar, dan memiliki kualitas yang baik. 2.Brand image dalam pengambilan keputusan mahasiswa memilih kampus sangat dipertimbangkan oleh mahasiswa, mereka memilih Perguruan Tinggi ini karena mempertimbangkan biaya yang harus dikeluarkan selama berkuliah, mereka melihat gedung yang sangat besar, dan mendengar rekomendasi dari teman - teman mereka bahwa Universitas Pamulang merupakan kampus yang berkualitas dibuktikan dengan saat ini memiliki Akreditas B pada program studi Manajemen S1. 3.Dengan menggunakan pengukuran pyramid framework atau kerangka kerja piramida marketing yang dikembangkan oleh Aryo Dioinegoro, maka dapat dilihat bahwa Universitas Pamulang berada di tahap ketiga, yaitu Awareness. Karena saat ini Universitas Pamulang sudah memiliki brand image atau citra merek yang sangat melekat di masyarakat khususnya mahasiswa.

\section{Saran}

Berdasarkan hasil kesimpulan di atas, maka dapat ditarik beberapa saran untuk brand image Universitas Pamulang sebagai berikut :

1.Brand image yang terdapat di Universitas Pamulang memang sudah diterima dengan baik di masyarakat, namun ada beberapa masyarakat yang terkadang meremehkan, mereka meremehkan bahwa dengan biaya terjangkau untuk berkuliah berarti Perguruan Tinggi tersebut kurang berkualitas. Hal ini mengharuskan Universitas Pamulang meningkatkan kualitasnya yang sudah baik. Seperti lebih memperketat seleksi masuk perguruan tinggi mahasiswa baru. 2. Mahasiswa memilih Universitas Pamulang untuk berkuliah pada awalnya karena memiliki biaya terjangkau, hal ini menyebabkan banyaknya mahasiswa yang berkuliah di Perguruan Tinggi ini. Khususnya di gedung A, mahasiswa terkadang mengeluhkan kepadatan lahan parkir, terutama pada saat UAS dan UTS. Mungkin Universitas Pamulang dapat mengelola parkiran lebih baik lagi, karena masih banyak mahasiswa yang parkir sembarangan dan makan tempat. 3.Penelitian yang selanjutnya dapat disarankan adalah mengambil topik ataupun tema yang berhubungan dengan kualitas yang dimiliki oleh Universitas Pamulang dengan menggunakan metode kuantitatif sehingga akan memberi masukan bagi lembaga yang bersangkutan.. 


\section{DAFTAR PUSTAKA}

Akbar, Adam, 2012, Vol, 12, No, 2, Analisis Pengaruh Citra Merek, Harga, dan Kualitas Produk Terhadap Keputusan Pembelian Notebook Toshiba, Universitas Gunadarma, Depok

Alma, Buchori. 2012. Manajemen Pemasaran dan Pemasaran Jasa. Alfabeta. Bandung.

Creswell, J.W, 2016, Research Design (Pendekatan Metode Kualitatif, Kuantitatif, dan Campuran), Yogyakarta, Pustaka Belajar.

Darsono, 2018, Kepemimpinan Dalam Pengembangan Perguruan Tinggi Yang Terjangkau Oleh Masyarakat Marginal : Refleksi Kritis Perkembangan Universitas Pamulang, Orasi IImiah, Universitas Negeri Yogyakarta, Yogyakarta.

Desy, Elfitra., 2016, Vol. 2 No.1., Pengaruh Brand Image,Lokasi dan Fasilitas Terhadap Keputusan Mahasiswa Memilih Universitas Pancabudi (Studi Kasus Mahasiswa Fakultas Ekonomi) Universitas Pancabudi.

David, Fred R, 2006, Manajemen Strategi, Buku 1, Edisi Kesepuluh, Salemba Empat, Jakarta.

Effendi, Usman, 2011, Asas Manajemen, PT Rajagrafindo Pesada, Depok.

Fandy, Tjiptono, Ph.D \& Gregorius, 2012, Pemasaran Stratejik, Edisi 2, CV. Andi Offset, Yogyakarta.

Fandy, Tjiptono, Ph.D, 2015, Strategi Pemasaran, Edisi 4. CV. Andi Offset, Yogyakarta.

Freddy, Rangkuti, 2006, Teknik Mengukur dan Strategi Meningkatkan Kepuasan Pelanggan, PT. Gramedia Pustaka Utama, Jakarta.

Hasan, Ali, 2009, Marketing, Medpress, Jogjakarta.

Kaelan, 2005, Metode Penelitian Kualitatif Bidang Filsafat, Yogyakarta, Paradigma.

Kotler, Philip and Kevin Lane Keller, 200, Manajemen Pemasaran, Edisi 12, PT. Indeks, Jakarta.

Kotler, Philip and Kevin Lane Keller, 2009, Manajemen Pemasaran, Edisi 13, jilid 1, PT. Indeks, Jakarta.

Kotler, Philip, dan Gary Amstrong, 2014, Principle Of Marketing, 15th edition, Pearson Prentice Hall, New Jersey.

Kotler, Philip and Kevin Lane Keller, 2016, Marketing Management, 15th Edition, Pearson Education Inc.

Lubis, Desy Irana Dewi, Rahmat Hidayat, 2017, Vol.5, No.1, pp, 15-24, Pengaruh Citra Merek dan Harga terhadap Keputusan Pembelian Pada Sekolah Tinggi IImu Manajemen Sukma Medan, Sekolah Tinggi Ilmu Manajemen Sukma, Medan.

Lutiary Eka Ratri, 2001, Hubungan Antara Citra Merek (Brand Image) Operator Selular dengan Loyalitas Merek (Brand Loyality) Pada Mahasiswa Pengguna Telepon Selular di Fakultas Ekonomi Reguler Universitas Diponogoro Semarang, Fakultas Psikolog Undip, Semarang.

Manooij, Marieke K. De, 2010, 3rd Edition, Global Marketing and Advertising Understanding Curtural Paradoexes, Sage, California.

Miles, B Mathew A. Michael Hiberman, 1992, Analisa Data Kualitatif (Terjemahan Teecep Rohendi) Jakarta, UI Press.

Moleong, Lexy, 2006, Metode Penelitian Kualitatif. Bandung, PT. Remaja Rosdakarya.

Moleong, 2007, Metoddologi Penelitian Kualitatif, PT. Remaja Rosdakarya, Offset, Bandung. Mulyatiningsih, Rudi, dkk, 2004, Bimbingan Pribadi - Sosial Belajar dan Karier, Grasindo, Jakarta.

Nasution, 2003, Metode Penelitian Naturalistik Kualitatif, Bandung, Tarsito.

Nurdiani, Nina, 2014, Vol 5, No.2, Teknik Sampling Snowball dalam Penelitian Lapangan, Architecture Department, Faculty of Engineering, BINUS University 
Pramudyo, Anung, 2012, Vol 1, No.1, Pengaruh Citra Merek Terhadap Loyalitas Melalui Kepuasan Sebagai Intervening, Akademi Manajemen Administrasi (AMA) "YPK", Yogyakarta.

Raco, 2010, Metode Penelitian Kualitaif Jenis, Karakteristik dan Keunggulannya, Gramedia Widiasarana Indonesia, Jakarta.

Rahman, Abdul, 2010, Panduan Pelaksanaan Administrasi Pajak Untuk Karyawan, Pelaku Bisnis dan Perusahaan, Nuansa, Bandung.

Retnoningsih, Endang, 2015, Vol.III No.1, Pengaruh Top Bramd Image BSI Terhadap Keputusan Mahasiswa Memilih Akademisi BSI, Komplek BSD.

Roslina, 2010, Citra Merek dan Dimensinya, Jurnal bisnis dan manajemen, Penerbit Fakultas Ekonomi dan Bisnis Universitas Lampung, Lampung.

Saladin, Djaslim, 2012, Manajemen Pemasaran, Analisis Perencanaan Pelaksanaan Unsur - Unsur Pemasaran, CV Linda Karya, Bandung.

Setiadi, Nugroho J, 2003, Perilaku Konsumen, Kencana, Jakarta.

Singh, Anurag, dan Punita Duhan, 2016, Managing Public Relations and Brand Image Through Social Media, Bussines Science Reference (an immprint of IGI Global), USA.

Sugiyono, 2004, Metode Penelitian Administrasi, Alfabeta, Bandung.

Sugiyono, 2008, Metode Penelitian Pendidikan, Cetakan kelima, Alfabeta, Bandung.

Sugiyono, 2011, Metode Penelitian Kualitatif dan Kuantitatif, Jakarta, CV Alfabeta.

Surakhmad, Winarno, 2009, Pendidikan Nasional Strategi dan Tragedi, Kompas, Jakarta.

Suyanto, Bagong dan Sutinah, 2005, Metode Penelitian Sosial Berbagai Alternatif Pendekatan, Jakarta, Kencana Prenada Media Group.

Terry, George R, 2006, Prinsip - Prinsip Manajemen, Bumi Aksara, Jakarta. 